\title{
Films in the Academic Library
}

$M r$. Bennett is a student at the Graduate Library School, University of Chicago.

D Oes the educational film confront the administrator of an academic library with a genuine service responsibility-or simply with a service opportunity? This is the central question for which an answer is sought in this paper.

In denying responsibility for film service, the academic librarian has generally used one or more of these arguments: (I) Although films may be effective communication tools, they are not appropriate library materials. (2) Films are not needed on the campus. (3) If needed, films and other nonbook materials should be serviced by a separate agency. (4) Integration of films with print and with the curriculum is extremely difficult if not impossible to accomplish. (5) Existing facilities and budgets do not permit the addition of film services.

Our purpose here is to discuss these five arguments, to the end that guideposts may be erected for academic librarians who have not yet resolved the question of responsibility for servicing films in their institutions.

\section{Are Films Appropriate Library Materials?}

Until the present century libraries worked chiefly with and through a single medium of communication-the book. Indisputably the book is highly effective, even though mainly for an elite consumer of facts and ideas, but other media have risen to challenge the book's pre-eminent position in the school, the library, and other social institutions.

The educational film is one of these newer media. Many public and academic librarians, concerned about their having effectively reached only a small portion of their constituencies through print, look to the motion picture as a possible means of extending the range of the library's service potential. Others deny that films can appropriately be brought into the library's service scheme.

There seems to be no inherent incompatibility between film and book. Objective comparison in terms of substance and function reveals a close relationship between the two media. The substance of both book and film ranges over the entire realm of knowledge. The primary function of each is the same: to convey facts and ideas. The essential difference between them is one of method. Whereas the book employs ordered sets of language symbols arranged on sheets of paper, the motion picture combines visual images with verbal elements on length of film which must be projected mechanically.

The real question is the deeper one: Just what is the academic library's function? If it is to function only as a "storehouse of print," films obviously must remain outside its service pattern. If, however, its function is the broader one of a "communications center" in the academic community, the library may properly include films and other nonbook materials.

\section{By Books Alone?}

Emerging educational patterns in colleges and universities make it obvious that books alone are no longer considered sufficient for effective instruction and research. 
The academic library's task is to provide the materials needed in the instructional and research programs. It follows then that the library must seriously consider the inclusion of nonbook materials which are increasingly believed essential in academic programs.

Enthusiasts claim that the film possesses a unique power in the sowing of ideas. Its versatility and liveliness probably make it more vivid and effective than any other medium man's ingenuity has yet devised. Yet much remains to be discovered about how films teach and how persons on different age levels learn from them, before films of optimum effectiveness can be made. It is probable that only by empirical methods can educators ultimately find answers to these questions. Until those answers are found, films need to be used extensively in realistic situations. To that end certain educational agencies must assume responsibility for acquiring films and making them available for use.

\section{Library or Separate Agency?}

The advantages of centralizing campus film services are generally recognized. It is obvious that the haphazard development on a departmental basis which has occurred on many campuses, lacking any coordination of resources and services, cannot be satisfactory. Nor can the expediency of adding films to existing extension services provide a satisfactory solution. Only through centralization can really effective service be given.

Wendt argues that a separate agency should be established for servicing films because the purely mechanical processes involved in servicing and caring for materials and equipment are totally unrelated to library routines. ${ }^{1}$ It is submitted, how-

1 Wendt, Paul, "A Central Audio-visual Aids Service in the University." Higher Education 2:11-13, May I, 1946. ever, that libraries can overcome the difficulties implied by adding trained personnel to the staff and by providing special facilities. The experience of academic libraries which have already embarked on film services strongly supports this belief. In one such library, the librarian has expressed the conviction that:

... in the long view their [audio-visual materials] contribution to instruction and especially to research will depend less upon the manipulation of mechanical devices in the classroom than upon the systematic acquisition and organization of audio-visual resources for instruction and research-that is, upon the creation of an audio-visual library in the literal, accepted sense. ${ }^{2}$

Only one of the functions of an audiovisual center outlined by Wendt does not clearly fall within the range of library service schemes. It is entirely appropriate that a library engage in ( $\mathrm{I}$ ) locating and evaluating good teaching materials; (2) keeping abreast of new developments in film production and use; (3) stimulating the faculty to use effective films; and (4) providing training in the operation of film equipment. Each of these has its counterpart among the functions libraries regularly perform in connection with printed materials.

The academic library might not easily perform the fifth of Wendt's functions, that of engaging in the actual production of effective audio-visual aids. However, it is not difficult to visualize a library-centered film service in which production activities are carried on. Library film specialists could readily perform the aspect of this function which is particularly emphasized, that of "see [ing] to it that the quality of production [in the university] is kept high enough so that the films will have permanent value."3 Here he is clearly stressing

2 Swank, Raynard C. "University of Oregon's Audiovisual Service." College and Research Libraries 9:300, October 1948.

3 Wendt, op. cit., p. 12. 
the role of the film expert as an advisor, and it seems to this writer unimportant whether that expert be on the staff of a separate agency or on the library staff.

Admittedly the library which decides to integrate films into its service pattern must overcome difficulties. Among these are: (1) securing proper budgetary support; (2) appointing trained personnel; (3) adapting existing facilities; (4) selecting films which are relevant to the educational program of the institution; and (5) organizing them for most effective use.

The separate agency encounters difficulties which are no less formidable, and which in the view of many audio-visual specialists make inadvisable the creation of a parallel agency for film service.

One of these specialists points out that the separate film center has had to develop new channels for transmitting and receiving requests, information, and evaluative data, and has had to combat the faculty attitude that films are "so many curricular

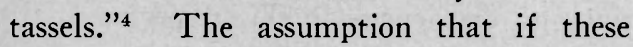
new instructional materials were introduced and distributed by the library, the faculty's acceptance would be more easily gained, is not necessarily sound. Much depends upon existing attitudes and other relevant factors. In some instances a separate agency might be more acceptable than a librarycentered service.

Librarians generally will not reject Schreiber's contention that since communication and distribution channels already exist between the library and other units of an academic institution, the library is a logical center for all instructional materials on the campus. Many will reinforce that assertion by underlining the organization already developed by the library for acquiring and processing materials, and the relative ease

1 Schreiber, Robert E., "Motion Picture Distribution as a Function of College Libraries." Film and Radio Guide $13: 36$, November 1946 . of adapting that organization to include films.

A further supporting argument which is of extreme practical importance to academic administrative heads is cited by Grady :

The economic disadvantages to the institution are apparent since separate quarters, another administrator, and another staff are often involved in the divided arrangement. ${ }^{5}$

Some librarians believe that the separation of books from related films, recordings, and other instructional materials creates hardships for both students and teachers. If patrons are obliged to "consult separate indexes, separate staffs, and possibly to visit separate buildings in order to assemble materials or references involving related content," 6 much time and effort is wasted, and the student or faculty member cannot be certain he has succeeded in securing all relevant materials available on the campus.

The heart of the matter is struck in Swank's refutation of arguments often advanced by opponents of library participation:

... audio-visual aids ought not be viewed in opposition to printed aids but should be integrated with them. Both are instructional aids used together in the same educational process, and if properly related supplement each other. When administered with vision and a clear understanding of educational objectives, their combination in the library should result not in the neglect of the audiovisual service, but in a broader and more adequate philosophy of the library itself-a philosophy involving both types of aids in new relationships. ${ }^{7}$

If an academic library seriously tries to fit the film into its scheme of appropriate services, the film must be given a meaningful place in the library's integration of its materials. The feasibility of so correlating

\footnotetext{
5 Grady, Marion B., "Nonbook Materials in a Teachers College Library."' College and Research Libraries $9: 312$, October 1948 .

6 Ibid.

Swank, op. cit., p. 300.
} 
films with older tools of communication as to make the library a "documentation" center-not merely a "bibliographical" center -may now be examined.

\section{Book and Film Integration}

Integration includes three functional components: ( $\mathrm{I}$ ) selecting instructional and research materials that meet existing or potential needs; (2) organizing them for effective use; and (3) continuously promoting their use whenever and wherever they are needed on the campus. Although none of their tasks is more important, librarians know there is no magic formula for bringing different kinds of materials into proper correlation with each other and with the many facets of an institution's teaching and research programs.

Experience may give a librarian considerable facility in dealing with integration's knotty problems, but the total curriculum of a college or university is an unstable fulcrum and the librarian's knowledge and skill an imperfectly wrought lever. The truth of this is implied in one librarian's confession that:

Many of us will freely admit that ... the arrangement of our collections, the types of services offered, and the attitudes actually encountered by the student in the library are not entirely in harmony with the educational philosophies, curriculums, and experiments present in our respective institutions. ${ }^{8}$

The size of the library provides one index to probable success in the area of integration. The larger and more complex the institutional program, the smaller are the librarian's chances of achieving an effective correlation of materials. The collections of university libraries, for example, tend to become so tremendous that beyond a rela-

Jesse, William H., "The University Library and its Services to Students." College and Research Libraries 7:302, October 1946. tively limited point the librarian's facility in relating them to an intricate curricular design diminishes rapidly.

Not all the reasons for a general failure in academic libraries to achieve full integration of printed materials are clear, but some are fairly obvious. Much of what libraries have acquired has remained unused; the same is true of many current purchases and gifts. Large groups of books superseded by later acquisitions are retained in the hope that future researchers may find them useful. An evidence of failure thus becomes an added impediment to success; it is clear that idle masses of materials become "a liability rather than an asset ... obscuring the presence of books which ought to be read."

The sheer magnitude of the world of print is in itself another obstacle, for it is impossible to select from so great a mass only those items which are relevant to a given institution's objectives. Recent surveys of university libraries point significantly to deficiencies in this respect.

The question of whether the integration of educational films with curricular programs creates problems greater than those encountered in the more familiar areas of print will now be examined.

Selection.-In considering the first stage of integration, it is submitted that the more severely limited the librarian's field of selection, the more sharply he will be able to focus his deliberation upon items considered for acquisition. It follows that since the number of available films is paltry beside the number of available books, it may be possible to make a more purposeful selection of films than of books.

Moreover, because of the relative expensiveness of films, it has become customary to preview them before placing

9 Branscomb, Harvie, Teaching. With Books: a Study of College Libraries. Clicago, Association of American Colleges and The American Library Association, 1940, p. 167. 
purchase orders. This practice affords the librarian an opportunity to learn just what a film contains and to determine, in consultation with faculty members, whether it relates in a meaningful way to any facet of the curriculum. The use of any comparable process in connection with printed materials is rare. Indeed, it is a commonplace to observe that in the press of administrative and other duties librarians become familiar with the integrational possibilities of only a small portion of the books they acquire.

Organization.-In the second stage of integration, that of organizing materials for effective use, the librarian's base of operations becomes somewhat less stable. The problems of so constructing indexes that patrons may easily find what they want, and of so arranging materials that they are really accessible, have long occupied the attention of administrators and catalogers. But it is apparent that here, too, no infallible formulas exist.

Cataloging techniques suitable for book materials have been carefully worked out, and applied or adapted in individual academic libraries. It has been found that these techniques can be readily adapted for the indexing of films.

The question of how best to arrange films for accessibility is not a troublesome one as long as collections remain relatively small. If film collections are allowed to grow as large as book collections, the problem may become complex, but the nature of films makes it unlikely that such increases will occur. For quite a long time then, the key to their accessibility will probably be careful subject indexing. The most satisfactory physical arrangement of films is probably a simple accession-number scheme.

Promotion.-Integration's most difficult problems occur in the third stage, when the librarian attempts to promote the use of library materials on the campus. Ingenuity of the highest order is demanded if the library administrator and his staff are to overcome the difficulties in this stage.

The usual promotional efforts involving browsing rooms, open-shelf collections, bibliographical assistance, exhibits, etc., have proved generally inadequate to the task. Promise of a closer approach to the goal of full integration is given in two recent trends: ( $\mathrm{I}$ ) functional building plans, in which attempts are made to bring materials and their users more nearly together, and to create a kind of laboratory situation; and (2) a broader conception of the library's teaching function, under which "scholars .... interested in the techniques of teaching" 10 would be appointed to the library staff.

Whatever means are adopted, however, it seems probable that the promotion of a meaningful and prolific use of films involves no greater difficulties than those which arise in helping to forward an effective use of printed materials.

Librarians who have denied admittance of films to their service schemes, believing a workable correlation with institutional aims and with older tools of communication to be impossible, have for the most part acted in good faith. Some, however, conscious of having fallen short of their integrational goals, have not cared to embrace what seems an impediment which might deepen their sense of failure.

However much one may be inclined to sympathize with this viewpoint, it seems obvious that librarians have an obligation to take a larger view in the matter. If films are really appropriate library materials, and if needs for them exist on the campus, the challenges of film-and-book integration must be met with all the resources and skill that the librarian can bring to bear.

10 Land, William G., "Functional College Library." Journal of Higher Education 18:91, February 1947. 


\section{Budgets and Facilities}

The core of another major area of opposition to educational films is the contention that limited budgets and facilities do not permit their addition to the service patterns of academic libraries. Realistic considerations are involved here which no librarian can afford to minimize.

An inflexible physical plant may effectively block the introduction of library film service. Few library buildings, however, are so completely unamenable to change that a resourceful librarian will be unable to improvise quarters for this new service. In its embryo stages a film service requires little space, and the facilities provided need not be elaborate.

If the demand for film service increases greatly, more space will probably be required. Such a demand will provide a significant measure of justification both for the initial space allotted and for expanded quarters, and at the same time reinforce the librarian's original decision to add films to the service design of his library. If no such demand arises, it will be clear that the librarian has misjudged campus needs or that he and his staff have failed to apply proper stimulus in promoting film use.

Budgetary limitations may also constitute a serious obstacle to starting film service in a college or university library. Those who plead the case of films in library service patterns readily admit that their introduction calls for increased budgets. Film prints are still relatively expensive, and the necessary equipment for storage and inspection is costly.

A library budget is not, however, merely an appropriated sum of money which the librarian parcels out for various types of expenditures. It is, or should be, a carefully formulated plan of service expressed in terms of what that service will cost. Budget requests based upon some mythical "right" of the library to a stipulated percentage of the total institutional budget, or upon some arbitrary per capita rate, are entirely unrealistic, and should be replaced by painstakingly projected figures based upon ascertainable costs of contemplated service

If the librarian acts upon this budgetary philosophy, the weaving of educational films into his service pattern will depend largely upon the quality of arguments he submits to administrative officials in justifying the new service.

Summary: Opportunity or Responsibility?

Although keenly aware of their responsibility for providing materials needed for instruction and research, academic librarians do not always agree as to what materials are entirely appropriate in their sphere of service. It is doubtful that very many seriously believe their province confined to print, but few have widened the service bases of their libraries to include films and other nonbook materials.

The educational film is clearly allied both in function and substance to those older media of communication which have gained universal sanction as library materials. As an instrument possessing unique virtues in disseminating facts and ideas, the film's already substantial role seems destined to increase in scope and importance. It is probable that its integration with many-faceted curricula can be accomplished with no more difficulty than that of other instructional and research materials.

The advisability of including films in an academic library would seem therefore to rest upon discernible realities which exist within the service area of the individual library. Once convinced that films are appropriate materials, the librarian who recognizes faculty and student needs for films is in a strong position to ask his administra-

(Continued on page 150) 


\section{Revision of the "Shaw List"}

Last summer the writer was asked by Wyman Parker, chairman of the A.C.R.L. College Libraries Section, to head a committee to study the need for revising the List of Books for College Libraries ("Shaw List") and to explore ways and means for such revision.

All librarians are earnestly asked to express their views to the committee. No questionnaire will be sent as it is felt that the voluntary response to this appeal will be a more valid measure of interest in the project.

The "Shaw List," so-called because it was compiled and edited by Charles B. Shaw, was published in I93 I by A.L.A. Publication was made possible through a grant from the Carnegie Corporation of New York. At that time the Corporation was engaged in making a large scale distribution of funds to aid in the development and strengthening of college book resources. Because there was no reliable standard for evaluating college book holdings for guidance in making grants, the Corporation named an advisory group, headed by William Warner Bishop, to prepare a list that would serve as a standard. The list was prepared for the group by Mr. Shaw.

The "Shaw List" served its immediate purpose so admirably that, in the two decades following its publication, it became generally accepted as a basic and vital tool for measuring the quality of college library book collections and as a buying guide for building up weak collections. The original list numbered about 14,000 titles and a supplement, appearing in 1938, added nearly 8,000 titles. Appropriateness and usefulness for undergraduate student reference and study were the principal criteria for selection and the final list represented the combined judgment of a considerable number of distinguished scholars, educators and librarians.

It has become increasingly evident that the "Shaw List" is growing obsolete as an evaluating standard and buying guide. If continued to be used for these purposes it must be brought up-to-date and a permanent policy for revision established; hence, the appointment of the "Shaw List" Revision Committee. Serving with the writer on this committee are Janet Agnew, Herbert Anstaett and Elkan Buchalter. These Pennsylvania librarians were chosen because of their nearness to Swarthmore College, where the original list was born, and because their geographic proximity makes committee meetings easy.

The U.S. Office of Education reports that there are more than 1800 small colleges in this country. It is to these small colleges that such a list is likely to prove most useful. The committee's first task, then, is to find out whether the librarians of these 1800 colleges do actually want such a list. If so, do they want a completely new "Shaw List," a supplement to the present list, or, perhaps, a quite different kind of list? For example, the new list, if needed, might be on the order of the H. W. Wilson Company's Standard Catalogs with monthly and annual cumulative supplements; it might be merely a checklist of the principal reference books and periodicals, like that published by the Southern Association of Colleges and Secondary Schools; or it might be completely revised every four or five years and supplemented by an A.C.R.L. monthly review publication on the order of The Booklist.

When the general sentiment with respect to these problems has been determined, the committee will, if necessary, explore ways and means for financing publication of the list, make recommendations for revision procedures, and furnish a list of candidates for the task of directing and editing the actual work of revision.

Let us have your opinions and your ideas, however conservative, reactionary, radical, revolutionary or impossible they may seem.Lee C. Brown, Pennsylvania Military College Library, Chester.

\section{Films in the Academic Library}

\section{(Continued from page 130 )}

tive superiors for increased funds and to demic community is well established. If a buttress his request with sound arguments.

Centralization as a basic principle in the handling of educational films in the acagood, separate agency has already been established, the librarian should probably do no (Continued on page I66) 


\section{Appointments}

Dorothy Larsen, formerly on the staff of the Teachers College Library at Columbia University, is now Librarian of Westmar College, Le Mars, Iowa.

Henry C. Hastings left the library of Brown University to accept appointment as reference librarian of Kenyon College, Gambier, Ohio.

Howard W. Williams is head of the Circulation Department at Swarthmore College Library. He was formerly on the library staff of Teachers College, Columbia University.

Forrest F. Carhart, Jr., was appointed as- sistant director of libraries at the University of Denver. Prior to coming to Denver, he was loan librarian at Iowa State College Library.

Mrs. Mignon E. Eliot was appointed librarian in charge of the reserve room at the University of Denver. Mrs. Eliot was most recently librarian at Miss Hutchinson's School, Memphis, Tenn.

Carlyle Stickler has accepted a position as documents librarian at Stanford University.

$\mathrm{LaVelle}$ Cox is supervisor of the Periodicals Section at the Princeton University Library.

\section{Retirement}

Edith M. Coulter retired after 42 years of service in university libraries. From 1907 to I9II she was in the Reference Department at Stanford. After that time she was in the
University of California Library at Berkeley, first in the Reference Department, and then as a member of the faculty of the School of Librarianship.

\section{Necrology}

Beatrice Barker, for 30 years head cataloger in the University of Oregon Library, died in 1949.

Robert J. Conklin, librarian and professor of English at Springfield College, Springfield, Mass., died on or about Dec. 25, 1949, in tragic circumstances. Led by his interest in problems of social and international understanding, he had accepted a Fulbright grant to teach for a year in the University of the
Philippines, where he had previously served as head of the English Department. During the Christmas vacation, he and his companion, a geographer from the university staff, while engaged in a scientific expedition into the little-known, mountainous region of northern Luzon, were killed by bandits. Prior to his appointment to the staff of Springfield College in 1936, he had taught English at Penn State, Purdue, and Muhlenberg College.

\section{Recent Personnel Changes in Foreign Libraries}

Bernard Kettle, formerly director of the Guildhall Library, London, died Aug. 9, 1949.

Dr. Hans Hansel was appointed provisional director of the Fulda Landesbibliothek on
Aug. I, 1949.

Dr. Simon Höpfl, director of the Bibliothek der Technischen Hochschule in Munich, died on Oct. 18, 1949.-Lawrence S. Thompson.

\section{Films in the Academic Library}

\section{(Continued from page 150)}

more than to effect a correlation of the library's activities with those of the film center.

If, on the other hand, the departments of the institution are attempting to meet their film needs with inadequate resources, without any plan for coordinating materials and equipment, the need for constructive action is manifest. The librarian may then justifiably believe that he has not only an opportunity but a genuine responsibility for securing necessary funds for a centralized film service which will adequately meet the needs of the community. 